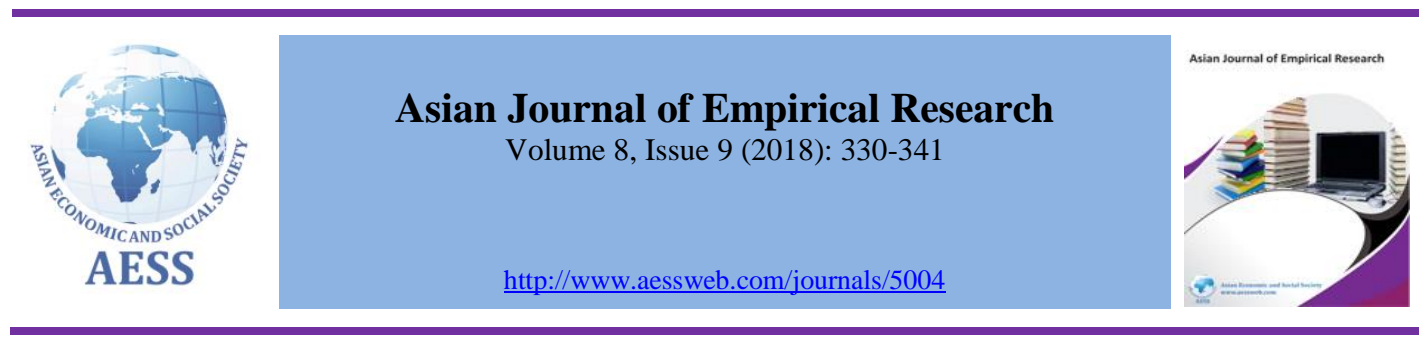

\title{
Perceived employee voice and organizational commitment: a case of Sri Lanka
}

\author{
Prasadika G. H. H. P. (ID) H. M. Nishanthi i
}

Department of Human Resource Management, University of Kelaniya, Sri Lanka

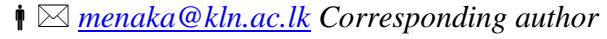

\section{ARTICLE HISTORY:}

Received: $26-$ Sep-2018

Accepted: $31-O c t-2018$

Online available: 19-Nov-

2018

\section{Keywords:}

Perceived employee voice, organizational commitment, employee line manager relationship, employee trust on senior management

\begin{tabular}{l}
\hline A BSTRA C T \\
Committed employees within the organization have become more \\
valuable for the organizations which highly focus on to sustain and \\
develop in this competitive business world. The main purpose of \\
this research was to identify the impact of perceived employee voice \\
on organizational commitment and identify the mediating effect of \\
employee line manager relationship and employee trust of senior \\
management on organizational commitment. To assess the \\
aforesaid relationships, a standard pre-tested questionnaire was \\
used to collect data. Correlation and simple regression analyses \\
were used to analyze data. It was found that perceived employee \\
voice has a significant impact on the organizational commitment. \\
Further, employee line manager relationship and employee trust on \\
senior management on organizational commitment partially \\
mediated the relationship among perceived employee voice and \\
organizational commitment and all the hypothesis were accepted. It \\
was further suggested to strengthen the relationship between \\
employees and management via allowing better voice to gain \\
commitment to the organisation.
\end{tabular}

\section{Contribution/ Originality}

Concepts of organizational commitment, employee voice, supervisor support and line manager relationship have been tested in international context but within the Sri Lankan context, there is limited investigation incorporating all four variables in a single study. Hence, current study contributes to fill this theoretical gap. Further, researchers did not find instances where these concepts examined in manufacturing industry in Sri Lanka.

DOI: 10.18488/journal.1007/2018.8.9/1007.9.330.341

ISSN (P): 2306-983X, ISSN (E): 2224-4425

How to cite: Prasadika G. H. H. P., and H. M. Nishanthi (2018). Perceived employee voice and organizational commitment: a case of Sri Lanka. Asian Journal of Empirical Research, 8(9), 330-341.

(C) 2018 Asian Economic and Social Society. All rights reserved 


\section{INTRODUCTION}

Today, it is visible that many organisations are in constant struggle to survive and accomplish their visions and goals due to the extended industrial competition and dynamic work settings. Keeping the best talent and getting their commitment as a source of competitive advantage again has become a challenge (Spagnoli and Caetano, 2012). Also, for the organizations achieve their targets and goals it is necessary to have greater commitment from their employees (Farndale et al., 2011). The concept of commitment has been widely researched by many scholars associating with diverse organisation related concepts such as socialization, protean career orientation (Nishanthi and Kailasapathy, 2017; Briscoe and Finkelstein, 2009), organizational values (Elizur and Koslowsky, 2001), CSR competencies (Caron and Fortin, 2014), industrial relations (Yuan et al., 2014), etc. When defining commitment, Mowday et al. (1979) identified it as an employee's belief in and acceptance of an organization's goals and values, a willingness to employ effort on behalf of the organization, and a desire to retain affiliation in the organization. Having a committed set of employees has become a key reason to survive and prosper in the current business environment. In order to get the commitment of the employees, organisations should be sensitive for their requirements of the work place and take their viewpoints in to consideration. Employee voice implies every possible occasion, which employee can influence the workplace decision and when the important decision or issues occur which affect employees, they should have the authority or right to raise their voice over it (Farndale et al., 2011). According to Holland et al. (2017), employee voice has a greater saying on deciding employee commitment towards the organization. Therefore, if the organization fail to give due consideration to employee voice, it can harm all organizational processes and the level of commitment of the employees in the workplace. Hence, it is essential to assess whether employee voice has become a decisive factor of employee commitment.

The previous studies (Farndale et al., 2011; Kim et al., 2018; Sawithri et al., 2017) on the relationship between employee voice and employee commitment, identified a direct impact and an indirect impact of employee voice on employee commitment. The direct relationship of voice of employee's and commitment can change according to employee relationship with immediate supervisors and employee trust with the organization management. Also, that employee relationship with line managers and their trust about the senior managers can mediate the main relationship of the employee voice and organizational commitment. Therefore, this study also considered relationship with line managers and their trust on the senior managers as the mediating variables. The current study, as a case analysis has selected XYZ (Pvt.) Ltd, a leading multinational rubber manufacturing and export company in Sri Lanka. Through policy requirements and the cultural observations, it was noted that $\mathrm{XYZ}$ is a company which considered employee commitment as the one of major value creating resources of the company. Hence, it was decided to carry out this study in the current organisation to test the validity of employee voice on uplifting employee commitment levels. Based on the diverse aspects of employee voice, problem statement of the study is formed as "is there any impact of employee voice, the employee line manager relationship and employee trust in senior management on the organizational commitment?"

Problem statement implied following research questions.

1. What is the impact on employee line manager relationship over the organizational commitment?

2. What is the impact on employee trust in senior management over the organizational commitment?

3 . What is the impact on employee voice over the employee line manager relationship?

4. What is the impact on employee voice over the employee trust in senior management?

5. What is the mediate effect of employee line manager relationship on the relationship of the organizational commitment and employee voice?

6. What is the mediate effect of employee trust in senior management on the relationship of the organizational commitment and employee voice? 


\section{LITERATURE REVIEW}

\subsection{Organizational commitment}

Muthuveloo and Rose (2005), identified employee commitment as the capacity of the employee to be loyal and aligned him/herself to the requirements, duties and responsibilities assigned by the organisation. Noting the same notion, Northcraft and Neale (1996) also identified employee commitment as an attitude reflecting an employee's level of faithfulness toward the organization. Shore and Martin (1989) have been considered Commitment as factor which more important to both employees and organization. Those who are committed to the organisation inherently feel a part of the organisation and feel a sense of duty as a member of the same organisation (Aghdasi et al., 2011). Employees who have high level of commitment toward the organization are more satisfy with their job and more like to stay with the organization for long time of period (Balu and Boal, 1987). March and Simon (1958) said that that commitment often encourage the exchange relationship of employees and the organization which employee commit to organization and get rewards and benefits from organization as a return.

\subsection{Employee voice}

The concept, employee voice is identified as the unrestricted communication of thoughts, recommendations, fears or opinions about work-related issues with the determination to improve organizational operations (Morrison, 2011). According to Mowbray et al. (2015), employee voice has seen a rapid increase in recent years, and various subjects have identified important factors relevant to the voice and results of employees. Freeman and Medoff (1984 as cited in Budd, 2004) defined employee voice as way to communicate with management and the ability to make meaningful input decisions. Folger (1977) also noted employee voice as a set of rules or procedures that allow individuals affected by a decision to present information relevant to that decision. Hence, it is clear that employee voice has been recognized as an important factor of an effective organization (Saunders et al., 1992). If the employees are given the chance and the path to voice their concerns/suggestions regarding work setup directly to the top and middle management, that would result in greater harmony and positive attitudes towards the management which intern result in high employee performance (Robinson et al., 2004).

\subsection{Employee-line manager relationship}

In order to build up strong relationships between employees and the line managers, employees should be given the opportunity to contribute in decision making. This creates positive attitudes towards organisation and the senior management as employees feel valued, recognized by his/her immediate supervisor. This would further result in greater job satisfaction building up a strong bond between employee and line manager (Korsgaard and Roberssons, 1995). However, the worth of the relationship between a supervisor and employee depends on several factors such as development of the supervisor, company size and structure, the physical location of the supervisors and employees, even the quality of the employee's work (Mayhew, 2017).

Further to above findings, Susan and Nasurdin (2016) found that supervisor support positively influences work engagement. Long (2017) said employees, supervisors and managers work together to meet individual, departmental, and corporate goals and relations between employees, supervisors, and managers need encouragement on individual and corporate level and also good working relationships between employees, supervisors and managers make company's success.

\subsection{Employee trust in senior management}

According to Cook and wall (1980) trust can be defined as belief on the trustworthiness of others and confidence in the ability of others. Considering the trust in the organization, it has attracted considerable attention due to its influence on the overall functioning and health of an organization and it has become one of the most influential factors determining the long term stability of a firm. 
Trust is important to all who aspire of social life and it strengthen the friendship (Gibbons, 2004). Trust also reduce cost (Bharadwaj and Matsuno, 2006) and also resolves political conflicts in organizations (Kelman, 2007). Shockley-Zalabak et al., 2000) said building trust within the organization is a one of the major goal of most organization why because it builds up positive employee behavior and professionalism within the organization and also positive work environment.

\section{HYPOTHESES DEVELOPMENT}

Holland et al. (2017) identified there are adequate research regarding on organizational commitment, but very limited studies on the association between variable of employee voice, supervisor support and trust in senior management which also identified the impact on the employee voice has on organizational commitment. Considering this gap in the Sri Lankan context following hypothesis is formed to measure the direct relationship between employee voice and organizational commitment.

$\mathrm{H}_{1}$ : There is a significant impact of perceived employee voice on organizational commitment.

There are two types of special exchange relationships, first employee with the senior management and secondly with the supervisor or the line manager (Alfes et al., 2013). Employees have trust on senior management and believe they have support from line manager according to social exchange theory, thus they respond positively and that cause to increase employee commitment. Both of these are a wide range of social exchange links the employees and the employer (Balain and Sparrow, 2009) have also research shown that trusted relationships with senior managers and employee line management ties Individual attitudes and behavior are differently (Settoon et al., 1996).

Considering the previous facts (Farndale et al., 2011), study assessed the employee line manager relationship and the employee trust in senior management as mediating variables and individually assessed both mediator effect on the independent and dependent variables. For that following hypotheses were postulated by the researcher basing past literature.

$\mathrm{H}_{2 \mathrm{~A}}$ : There is a significant impact of perceived employee voice on employee line manager relationship. $\mathrm{H}_{2 \mathrm{~B}}$ : There is a significant impact of employee - line manager relationship on organizational commitment.

$\mathrm{H}_{3 \mathrm{~A}}$ : There is a significant impact of perceived employee voice on employee trust in senior management.

$\mathrm{H}_{3 \mathrm{~B}}$ : There is a significant impact of employee trust in senior management on organizational commitment.

Considering the assessing the individual mediating effect of the employee line manager relationship and the employee trust in senior management on employee voice and organizational commitment following hypotheses were formed for this study.

$\mathrm{H}_{4}$ : The relationship between perceive employee voice and organizational commitment is mediated by the employee - line manager relationship.

$\mathrm{H}_{5}$ : The relationship between perceive employee voice and organizational commitment is mediated by the employee trust in senior management.

\section{METHOD}

\subsection{Research design}

Considering the nature of study, this study can be categorized as quantitative research. This can also be regarded as a cross sectional study. According to Sekaran (2010) this is a descriptive study which explains the relationship of the variables and answer the "what" question implies by the researcher. Unit of analysis of this study is individual staff level employee in XYZ Pvt. Ltd. Simple random 
sampling method was used to select the sample. The researchers used cross sectional data collected at one point of time in the research.

\subsection{Population, sample of the study}

The population concerned for the research study includes staff level employees who represented the team leader and above positions in the XYZ (Pvt.) Ltd. The study is based on primary data collected from staff level employees in company. There are 700 staff members and from this population a sample of 150 staff members were selected randomly from the different manufacturing plant of XYZ (Pvt.) Ltd in Sri Lanka. Study was mainly based on both primary data, collected through a survey and secondary data, taken from relevant literature. Data were collected through a standard questionnaire which was developed adopting existing measurement scales found in literature which are already tested by previous researchers and which met the acceptable standards of validity and reliability. Collected data were analyzed using the package SPSS version 23.

\subsection{Measures}

Data were collected through standard questionnaire which was developed based on existing measurement scale in literature which are already tested and validated by previous researchers. Employee voice was assessed using the scale derived from the employee survey of the 1998, Workplace Employee Relations Survey (WERS) in the United Kingdom which was the most frequently used measurement in the literature. Organizational commitment was tested utilizing the scale of six, five point Likert scale items from Mowday et al. (1979). Employee-line manager relationship was assessed using the measurement scale derived from Cook and Wall (1980) and Undén (1996) which also included five Likert scale items. The concept of employee trust in senior management was tested by four items adopted from Cook and Wall (1980) which was again ranged from strongly disagree to strongly agree on a five point Likert scale.

\subsection{Data Collection and analysis techniques}

To collect primary data, survey was carried out within three weeks of the month of November, 2017. The survey questionnaire had main two sections naming as A \& B. Section A included six demographic questions relating to age, gender, work pattern, contract type, job grade and working years in current company and these demographic items are relating to current study and used in the analysis to describe the sample combination only. Section B included major four parts which tested the independent, dependent and mediator variables of employee voice, organizational commitment, employee-line manager relationship and employee trust in senior management.

Data were analyzed using the Statistical Package for Social Sciences (SPSS) version 23. Frequencies and descriptive statistics were used elaborate the sample composition and the individual behavior of the major four variables. Formulated hypotheses were tested based on the collected data by using correlation analysis, simple regression analysis.

\section{DATA ANALYSIS}

\subsection{Sample description}

In the selected 150 sample, only 110 staff members effectively responded to questionnaires $(73.33 \%)$ Considering the sample, majority in the sample were male staff members and sample included $22.7 \%$ of female staff members, there were $82.7 \%$ permanent staff members $10 \%$ trainees and $7.3 \%$ probation employees included in the sample. The selected sample included $33.6 \%$ of employees in the age group of $20-29$ years and $18.2 \%$ in age group of $40-49$ years. Greater $48.2 \%$ of employees represented the range of $30-39$ years. 08 senior managers responded (7.5\%). Seventeen senior executives (17), thirtysix (36) executives, thirty-five (35) officers and fourteen (14) team member/leaders also responded. Out of all respondents, $2.7 \%$ have worked 21-25 years in the company, there were $20 \%$ of employees who have worked within less than 1 year. $19.1 \%$ of employees from the data set have worked in the company both within 1- 5 years and $6-10$ years. $21.8 \%$ of responded from the data set have worked 
in the company $11-15$ years. There were $17.3 \%$ of responded in the have been working $16-20$ years in the company.

\subsection{Reliability}

Table 1: Results of Cronbach's alpha

\begin{tabular}{lc}
\hline Variable & Cronbach's Alpha \\
\hline Employee Voice (IV) & 0.713 \\
Organizational Commitment (DV) & 0.744 \\
Employee - Line Manager Relationship (MV 1) & 0.779 \\
Employee Trust in Senior Management (MV2) & 0.733 \\
\hline
\end{tabular}

Source: Survey data, 2017

Cronbach's alpha coefficient was used to test the reliability of the measurement scales and the collected data set. All research variables exceeded the acceptable standard of reliability analysis of 0.70 (Nunally and Bernstein, 1994 as cited in Ismail et al., 2009). The results of Cronbach's Alpha test for Satisfaction internal reliability of each instrument is satisfactory. All the instruments had a high degree of internal consistency reliability.

\subsection{Correlation analysis}

Table 2: Correlations of the variables

\begin{tabular}{lccc}
\hline Variable & $\begin{array}{c}\text { Organizational } \\
\text { Commitment }\end{array}$ & $\begin{array}{c}\text { Employee } \\
\text { Voice }\end{array}$ & $\begin{array}{c}\text { Employee Line Manager } \\
\text { Relationship }\end{array}$ \\
\hline Organizational Commitment & 1 & & \\
Employee Voice & $0.494^{* *}$ & & \\
Employee Line Manager Relationship & $0.315^{* *}$ & $0.508^{* *}$ & $0.239^{*}$ \\
Trust in Senior Management & $0.385^{* *}$ & $0.372^{* *}$ & \\
$* *$ Correlation is significant at the 0.01 level (2-tailed). & & \\
$*$ * Correlation is significant at the 0.05 level (2-tailed). & & \\
\hline
\end{tabular}

Source: Survey data, 2017

Pearson correlations were computed between perceived employee voice and organizational commitment suggesting that there is a moderate positive relationship between employee voice and organizational commitment. As the significant value (0.01) is smaller the desired level of significance $(0.05)$ at $95 \%$ confidential level, the found correlation coefficient of 0.494 is statistically significant. So, there is statistical evidence to claim that there is a significant relationship between perceived employee voice of XYZ company and its employees' organizational commitment.

And also Pearson correlations were computed between employee voice and employee line manager relationship suggesting that there is a strong positive relationship between employee voice and employee line manager relationship. As the significant value (0.01) is smaller the desired level of significance (0.05) at $95 \%$ confidential level, the found correlation coefficient 0.508 is statistically significant. So, there is statistical evidence to claim that there is a significant relationship between perceived employee voice of XYZ company and its employee line manager relationship.

Pearson correlation computed between employee line manager relationship and organizational commitment was 0.315 which was statistically significant. So, there is statistical evidence to claim that there is a significant week positive relationship between employee line manager relationship and organizational commitment. 
According to tested result of Pearson Correlation is 0.372 suggesting that there is a week positive relationship between employee voice and employee trust in senior management. As the significant value $(0.01)$ is smaller the desired level of significance $(0.05)$ at $95 \%$ confidential level, the found correlation coefficient is statistically significant relationship between perceived employee voice of $\mathrm{XYZ}$ company and its employee trust in senior management.

Finally, Pearson correlations were computed between employee trust in senior management and organizational commitment. According to result Pearson Correlation is .385 suggesting that there is a week positive relationship between employee trust in senior management and organizational commitment. As the significant value (0.01) is smaller the desired level of significance (0.05) at 95\% confidential level, the found correlation coefficient is statistically significant between employee trust in senior management of a XYZ company and its employees' organizational commitment.

\subsection{Hypothesis testing}

Simple Regression analysis is used to test the hypothesis in the research study and following results were elaborate using the simple regression analysis.

\section{Table 3: Results of simple regression analysis}

\begin{tabular}{|c|c|c|c|c|c|}
\hline \multirow{2}{*}{ Method } & \multicolumn{5}{|c|}{ Liner } \\
\hline & $\mathbf{H}_{1}$ & $\mathbf{H}_{2 \mathrm{~A}}$ & $\mathbf{H}_{2 B}$ & $\mathbf{H}_{3 \mathrm{~A}}$ & $\mathrm{H}_{3 \mathbf{B}}$ \\
\hline R Square & 0.244 & 0.258 & 0.099 & 0.139 & 0.148 \\
\hline Adjusted R Square & 0.237 & 0.251 & 0.091 & 0.131 & 0.140 \\
\hline $\mathrm{F}$ & 34.879 & 37.517 & 11.860 & 17.368 & 18.766 \\
\hline Significance & 0.000 & 0.000 & 0.001 & 0.000 & 0.000 \\
\hline $\mathrm{B}-$ constant & 2.276 & 2.068 & 2.959 & 2.785 & 2.396 \\
\hline Standardized Beta & 0.494 & 0.508 & 0.315 & 0.372 & 0.385 \\
\hline
\end{tabular}

Source: Survey data, 2017

$\mathrm{H}_{1}$ : There is a significant impact of perceived employee voice on organizational commitment.

As per the result of simple regression analysis between the two variables tests, the hypothesis is accepted, however the impact is week. The b value of the equation, the slope of the regression, is .494 at a significant level of 0.000. F value $=34.879(\mathrm{P}=0.000)$, which suggests that perceived employee voice has significantly explained $24 \%$ (based on $\mathrm{R}$ square value) of the variance of organizational commitment. Hence, data support the hypothesis that there is a significant impact of perceived employee voice and organizational commitment.

$\mathrm{H}_{2 \mathrm{~A}}$ : There is a significant impact of perceived employee voice on employee line manager relationship.

As per the result of simple regression analysis between the two variables tests, the hypothesis is accepted. The impact is $25 \%$ at a significant level of 0.00 . as indicated by $\mathrm{R}$ square value. Hence, it could be accepted that there is a significant impact of perceived employee voice and employee line manager relationship.

$\mathrm{H}_{2 \mathrm{~B}}$ : There is a significant impact of employee - line manager relationship on organizational commitment.

The hypothesis $\mathrm{H}_{2 \mathrm{~B}}$ is also accepted as $9.1 \%$ of the variations ( $\mathrm{R}$ square) in organizational commitment is due to the strength of employee- line manager relationship. However, this impact is quite low but the data can be said to be significant at $99 \%$ confidence level. Hence, $\mathrm{H}_{2 \mathrm{~B}}$ is also accepted. 
$\mathrm{H}_{3 \mathrm{~A}}$ : There is a significant impact of perceived employee voice on employee trust in senior management.

As per the result of simple regression analysis between the two variables tests, the hypothesis is accepted. The $\mathrm{R}$ square value is $14 \%$ at a significant level of .00 . Therefore, data support the hypothesis that there is a significant impact of perceived employee voice and employee trust in senior management.

$\mathrm{H}_{3 \mathrm{~B}}$ : There is a significant impact of employee trust in senior management on organizational commitment.

Hypothesis- $\mathrm{H}_{3 в}$ suggests that there is a significant impact of trustworthiness of senior management on enhancing organizational commitment. This hypothesis is also accepted as the R square indicates an effect of $14.8 \%$ on employee commitment. As the impact is significant at a confidence level of $99 \%$, this hypothesis is also accepted.

\subsection{Mediating effect}

$\mathrm{H}_{4}$ : The relationship between perceive employee voice and organizational commitment is mediated by the employee - line manager relationship.

A series of regression analyses were used to test the employee line manager relationship as a mediator in between impact of perceive employee voice and organizational commitment. Thereafter, it was found that employee line manager relationship partially mediates the relationship between perceive employee voice and organizational commitment since the independent variable affected the dependent variable upon regressing the dependent variable on both the independent variable and on the mediator. The result indicate that perceive employee voice could significantly impact organizational commitment $(\beta=0.494, p<0.000)$ and perceive employee voice could significantly impact employee line manager relationship $(\beta=0.508, p<0.000)$ which in turn could increase organizational commitment $(\beta=0.315, p<0.001)$. In addition to that the mediation impact of employee line manager relationship between of perceive employee voice and organizational commitment was developed by using following equation.

Equation 01: Mediation impact of Employee-line manager Relationship

$$
\text { Mediating Effect }=\left(\mathrm{r}_{1}{ }_{1}\right)-\left(\mathrm{r}^{2}{ }_{2 \mathrm{~A}} \times \mathrm{r}^{2}{ }_{2 \mathrm{~B}}\right)
$$

Direct impact of employee voice on organizational commitment $\left(\mathrm{r}^{2}{ }_{1}\right)=0.244$

Indirect impact of employee line manager relationship on the organizational commitment

$$
\begin{aligned}
& =r^{2}{ }_{2 \mathrm{~A}} \times \mathrm{r}^{2}{ }_{2 \mathrm{~B}} \\
& =0.258 \times 0.999 \\
& =0.257
\end{aligned}
$$

Where,

$$
\begin{aligned}
& =\left(\mathrm{P}_{2 \mathrm{~A}} \times \mathrm{P}_{2 \mathrm{~B}}<0.05\right. \\
& =(0.000 \times 0.001)<0.05
\end{aligned}
$$

Mediating impact of employee -line manager relationship

$$
\begin{aligned}
& =\left(\mathrm{r}^{2}\right)-\left(\mathrm{r}^{2}{ }_{2 \mathrm{~A}} \times \mathrm{r}^{2}{ }_{2 \mathrm{~B}}\right) \\
& =0.244-0.257 \\
& =-0.013
\end{aligned}
$$


According to the above equation 01, the mediating effect of employee - line manager , in the impact between perceive employee voice and organizational commitment is -0.013 Although there is a negative value mediating impact, by considering the significance value of three variables the researcher was addressed that employee - line manager relationship partially mediates the impact between perceive employee voice and organizational commitment $(p<0.05)$ since the independent variable affected the dependent variable upon regressing the dependent variable on both the independent variable and on the mediator.

Based on above analyses, it can be deduced that there is a partial mediating effect of employee - line manager relationship on impact between perceive employee voice and organizational commitment.

Therefore, the hypothesis $4\left(\mathrm{H}_{4}\right.$ : The relationship between perceive employee voice and organizational commitment is mediated by the employee - line manager relationship) in the current research is accepted.

And also a series of regression analyses were used to test the employee trust in senior management as a mediator in between impact of perceive employee voice and organizational commitment. Thereafter, it was found that employee trust in senior management partially mediates the relationship between perceive employee voice and organizational commitment since the independent variable affected the dependent variable upon regressing the dependent variable on both the independent variable and on the mediator. The result indicate that perceive employee voice could significantly impact organizational commitment $(\beta=0.494, \mathrm{p}<0.000)$ and perceive employee voice could significantly impact employee trust in senior management $(\beta=0.372, \mathrm{p}<0.000)$ which in turn could increase organizational commitment $(\beta=0.385, \mathrm{p}<0.000)$.

In addition to that the mediation impact of employee trust in senior management on perceive employee voice and organizational commitment was developed by using following equation.

Equation 02: Mediation impact of Employee Trust in Senior Management

$$
\text { Mediating Effect }=\left(\mathrm{r}^{2}{ }_{1}\right)-\left(\mathrm{r}^{2}{ }_{2 \mathrm{~A}} \times \mathrm{r}^{2}{ }_{2 \mathrm{~B}}\right)
$$

Direct impact of employee voice on organizational commitment $\left(\mathrm{r}^{2}{ }_{1}\right)=0.244$

Indirect impact of employee trust in senior management on the organizational commitment

$$
\begin{aligned}
& =r^{2}{ }_{3 \mathrm{~A}} \times \mathrm{r}^{2}{ }_{3 \mathrm{~B}} \\
& =0.139 \times 0.148 \\
& =0.020
\end{aligned}
$$

Where,

$$
\begin{aligned}
& \mathrm{P}_{3 \mathrm{~A}} \times \mathrm{P}_{3 \mathrm{~B}}<0.05 \\
& 0.000 \times 0.000<0.05
\end{aligned}
$$

Mediating impact of employee trust in senior management on the organizational commitment

$$
\begin{aligned}
& =\left(\mathrm{r}^{2}{ }_{1}\right)-\left(\mathrm{r}^{2}{ }_{3 \mathrm{~A}} \times \mathrm{r}^{2}{ }_{3 \mathrm{~B}}\right) \\
& =0.244-0.020 \\
& =0.224
\end{aligned}
$$

According to the above equation 02, the mediating effect of employee trust in senior management, on the impact between perceive employee voice and organizational commitment is 0.224 Although there is a positive mediating impact, by considering the significance value of three variables the researcher was addressed that employee trust in senior management partially mediates the impact between perceive employee voice and organizational commitment $(\mathrm{p}<0.05)$ since the independent variable 
affected the dependent variable upon regressing the dependent variable on both the independent variable and on the mediator.

Based on above analyses, it can be reasoned that there is a partial mediating effect of employee trust in senior management on impact between perceive employee voice and organizational commitment. Therefore, the hypothesis $5\left(\mathrm{H}_{5}\right.$ : The relationship between perceive employee voice and organizational commitment is mediated by the employee trust in senior management) in the current research is accepted.

\section{CONCLUSION AND DISCUSSION}

Findings revealed that there was a significant the impact of perceived employee voice on organizational commitment of staff members in the XYZ (pvt.) Ltd. And also there is a partial mediating effect of employee trust in senior management on impact between perceive employee voice and organizational commitment. Also there was a partial mediating effect from employee line manager relationship on impact between perceive employee voice and organizational commitment. Result implies that respectively -0.013 and 0.224 partial mediating effect from employee line manager relationship and employee trust in senior management.

The main objective of this study was significant impact of Employee Voice on Organizational Commitment of staff level employees within the XYZ (Pvt.) Ltd. The findings of this study are useful for identifying the reason in order to take action for increase the organizational commitment.

Further, this study is useful for the various professionals in the business field, especially for the private sector organizations to get the insights from the results and recommendations for this analyzed problem. In addition to that, this provides the information to review and revise their HRM practices in a way of increasing the organizational commitment by increasing the voice of the employees and increasing the trust in an organization also maintaining the good relationship within employee and the line managers with the support from previous researches.

And also this provides variety of information related to this context for who are interested. Furthermore, this study provides theoretical and practical knowledge with the research guide for the university students and other person who are interested to learn.

\subsection{Recommendations}

It is recommended that company should pay more attention on improving employee voice and the power of the voice. That mostly help to organizations for improve employee commitment towards the organization. Company does not have any employee unions and employees do not have the chance to express their voice through unions. It is good company give chances to employees to make voice through unions. And also recommended that maintain the good supervisor employee relationship to increase organizational commitment.

\subsection{Limitations}

Population selected for the research is too narrow because it is limited to only one organization. Questionnaire response may be wrong due to they deliberately change the answer. The employees might not respond genuinely because of fear of mentioning ill of the organization. Some employees were unable to take time to read well and answer the questionnaire due to lack of time they had a result of high work pressure. Questionnaire was distributed only in English language. Some employees might have difficulty in understanding the problem of English language and that occurred to them not answering the questions well and the responses were limited only to the 110 staff level employees in loadstar company out of the all 700 staff employees. It was more difficulties occurred when the recollect the complete questionnaire. Time which had to conduct the overall research were very limited and it can badly effect the finishing quality of the research study. 
Funding: This study received no specific financial support.

Competing Interests: The authors declared that they have no conflict of interests.

Contributors/Acknowledgement: All authors participated equally in designing and estimation of current research.

Views and opinions expressed in this study are the views and opinions of the authors, Asian Journal of Empirical Research shall not be responsible or answerable for any loss, damage or liability etc. caused in relation to/arising out of the use of the content.

\section{References}

Aghdasi, S., Kiamanesh, A. R., \& Ebrahim, A. N. (2011). Emotional intelligence and organizational commitment: testing the mediatory role of occupational stress and job satisfaction. Procedia Social and Behavioral Sciences, 29(1), 1965-1976. view at Google scholar / view at publisher

Alfes, K., Truss, C., Soane, E. C., Rees, C., \& Gatenby, M. (2013). The relationship between line manager behavior, perceived HRM practices, and individual performance: Examining the mediating role of engagement. Human resource management, 52(6), 839-859. view at Google scholar / view at publisher

Balain, S., \& Sparrow, P. (2009). Engaged to perform: a new perspective on employee engagement: academic report. Centre for Performance-led HR, Lancaster University Management School. United Kingdom. view at Google scholar

Balu, G. J., \& Boal, K. B. (1987). Conceptualizing how job involvement and organizational commitment affect turnover and absenteeism. Academy of Management Review, 12, 288-300. view at Google scholar / view at publisher

Bharadwaj, N., \& Matsuno, K. (2006). Investigating the antecedents and outcomes of customer firm transaction cost savings in a supply chain relationship. Journal of Business Research, 59(1), 62-72. view at Google scholar / view at publisher

Briscoe, J. P., \& Finkelstein, L. M. (2009). The "new career" and organizational commitment: Do boundaryless and protean attitudes make a difference? Career Development International, 14(3), 242-260. view at Google scholar / view at publisher

Budd, J. W. (2004). Employment with a human face: Balancing efficiency, equity, and voice. Cornell University Press. view at Google scholar / view at publisher

Caron, M. A., \& Fortin, A. (2014). Accountants' construction of CSR competencies and commitment. Sustainability Accounting. Management and Policy Journal, 5(2), 172-196. view at Google scholar / view at publisher

Cook, J., \& Wall, T. (1980). New work attitude measures of trust, organizational commitment and personal need non-fulfilment. Journal of Occupational and Organizational Psychology, 53(1), 39-52. view at Google scholar / view at publisher

Elizur, D., \& Koslowsky, M. (2001). Values and organizational commitment. International Journal of Manpower, 22(7), 593-599. view at Google scholar

Farndale, E., Van Ruiten, J., Kelliher, C., \& Hope-Hailey, V. (2011). The influence of perceived employee voice on organizational commitment: An exchange perspective. Human Resource Management, 50(1), 113-129. view at Google scholar / view at publisher

Folger, R. (1977). Distributive and procedural justice: Combined impact of voice and improvement on experienced inequity. Journal of personality and social psychology, 35(2), 108-119. view at Google scholar / view at publisher

Gibbons, D. E. (2004). Friendship and advice networks in the context of changing professional values. Administrative Science Quarterly, 49(2), 238-262. view at Google scholar

Holland, P., Cooper, B., \& Sheehan, C. (2017). Employee voice, supervisor support, and engagement: The mediating role of trust. Human Resource Management, 56(6), 915-929. view at Google scholar / view at publisher

Ismail, A., Yao, A., \& Yunus, N. K. Y. (2009). Relationship between occupational stress and job satisfaction: an empirical study in Malaysia. Romanian Economic Journal, 12(34), 3-29. view at Google scholar

Kelman, S. (2007). Unleashing change: A study of organizational renewal in government. Public Administration, 87(1), 227-253. view at Google scholar / view at publisher 
Kim, M., Choi, L., Borchgrevink, C. P., Knutson, B., \& Cha, J. (2018). Effects of Gen Y hotel employee's voice and team-member exchange on satisfaction and affective commitment between the US and China. International Journal of Contemporary Hospitality Management, 30(5), 2230-2248. view at Google scholar / view at publisher

Korsgaard, M. A., \& Roberson, L. (1995). Procedural justice in performance evaluation: The role of instrumental and non-instrumental voice in performance appraisal discussions. Journal of management, 21(4), 657-669. view at Google scholar / view at publisher

Long, N. (2017). Relationship between employee, supervisor \& manager. Retrieved from bizfluent.com: $\quad$ https://bizfluent.com/info-12048309-relationship-between-employeesupervisor-manager.html.

March, J. G., \& Simon, H. A. (1958). Organizations. New York: Wiley.

Mayhew, R. (2017). Supervisor \& supervisee relationships in the workplace. Retrieved from work.chron.com: http://work.chron.com/supervisor-supervisee-relationships-workplace-17796.html.

Morrison, E. W. (2011). Employee voice behavior: Integration and directions for future research. Academy of Management Journal, 5(1), 373-412. view at Google scholar / view at publisher

Mowbray, P. K., Wilkinson, A., \& Tse, H. H. (2015). An integrative review of employee voice: Identifying a common conceptualization and research agenda. International Journal of Management Reviews, 17(3), 382-400. view at Google scholar / view at publisher

Mowday, R. T., Steers, R. M., \& Porter, L. W. (1979). The measurement of organizational commitment. Journal of Vocational Behavior, 14(2), 224-247. view at Google scholar

Muthuveloo, R., \& Rose, R. C. (2005). Typology of organisational commitment. American Journal of Applied Science, 2(6), 1078-1081. view at Google scholar / view at publisher

Nishanthi, H. M., \& Kailasapathy, P. (2017). Employee commitment: the role of organizational socialization and protean career orientation. South Asian Journal of Human Resources Management, 5(1), 1-27. view at Google scholar / view at publisher

Northcraft, T., \& Neale, H. (1996). Organisation behaviour. London: Prentice-Hall. Nwagwu, CC (1997). The environment of crisis in the Nigerian education system. Journal of Comparative Education, 33(1), 87-95.

Robinson, D., Perryman, S., \& Hayday, S. (2004). The drivers of employee engagement report 408. Institute for Employment Studies, UK.

Saunders, D. M., Sheppard, B. H., Knight, V., \& Roth, J. (1992). Employee voice to supervisors. Employee Responsibilities and Rights Journal, 5(3), 241-259. view at Google scholar

Sawithri, L. D., Nishanthi, H. M., \& Amarasinghe, K. G. (2017). The impact of employer-employee relations on employee commitment: a case from Sri Lanka. Kelaniya Journal of Human Resource Management, 12(2), 174-192. view at Google scholar / view at publisher

Sekaran, U. (2010). Research methods for business: A skill building approach (4th ed.). New Delhi: Wiley India. view at Google scholar / view at publisher

Settoon, R. P., Bennett, N., \& Liden, R. C. (1996). Social exchange in organizations: Perceived organizational support, leader-member exchange, and employee reciprocity. Journal of applied psychology, 81(3), 219. view at Google scholar / view at publisher

Shockley-Zalabak, P., Ellis, K., \& Winograd, G. (2000). Organizational trust: What it means, why it matters. Organization Development Journal, 18(4), 35-43. view at Google scholar

Shore, L. M., \& Martin, H. J. (1989). Job satisfaction and organizational commitment in relation to work performance and turnover intentions. Human relations, 42(7), 625-638.

Spagnoli, P., \& Caetano, A. (2012). Personality and organisational commitment: The mediating role of job satisfaction during socialisation. Career Development International, 17(3), 255-275. view at Google scholar / view at publisher

Susan, C. L., \& Nasurdin, A. M. (2016). Supervisor support and work engagement of hotel employees in Malaysia. Gender in Management, 31(1), 2-17. view at Google scholar / view at publisher

Undén, A. L. (1996). Social support at work and its relationship to absenteeism. Work \& Stress, 10(1), 46-61. view at Google scholar / view at publisher

Yuan, L., Yu, Y., Li, J., \& Ning, L. (2014). Occupational commitment, industrial relations and turnover intention: Empirical evidence from China. Chinese Management Studies, 8(1), 66-84. view at Google scholar / view at publisher 